\title{
Thyroid Follicular Cell Loss of Differentiation Induced by MicroRNA miR-17-92 Cluster Is Attenuated by CRISPR/Cas9n Gene Silencing in Anaplastic Thyroid Cancer
}

\author{
Cesar Seigi Fuziwara, Kelly Cristina Saito, and Edna Teruko Kimura
}

\begin{abstract}
Background: Loss of the expression of thyroid differentiation markers such as sodium iodide symporter (NIS) and, consequently, radioiodine refractoriness is observed in aggressive papillary thyroid cancer and anaplastic thyroid cancer (ATC) that may harbor the $\mathrm{BRAF}^{\mathrm{V} 600 \mathrm{E}}$ mutation. Activation of the $\mathrm{BRAF}^{\mathrm{V} 600 \mathrm{E}}$ oncogene in thyroid follicular cells induces the expression of the miR-17-92 cluster that comprises seven mature microRNAs (miRNAs). miRNAs are a class of endogenous small RNAs $(\sim 22 \mathrm{nt})$ that regulate gene expression posttranscriptionally. Indeed, miR-17-92 is overexpressed in ATC, and in silico prediction shows the potential targeting of thyroid transcription factors and tumor suppressor pathways. In this study, we aimed to investigate the role of the miR-17-92 cluster in thyroid cell differentiation and function.

Methods: miR-17-92 silencing was performed using CRISPR/Cas9n-guided genomic editing of the miR-17-92 gene in the KTC2 ATC cell line, and miR-17-92 cluster or individual miRNAs were overexpressed in $\mathrm{PCCl} 3$ thyroid cells to evaluate the influence in thyroid cell differentiation and cell function.

Results: In this study, we demonstrate that CRISPR/Cas9n gene editing of the miR-17-92 cluster results in promotion of thyroid follicular cell differentiation (NIS, thyroperoxidase, thyroglobulin, PAX8, and NKX2-1 expression) in the KTC2 ATC cell line and inhibits cell migration and proliferation by restoring transforming growth factor beta (TGF- $\beta$ ) signaling pathway responsiveness. Moreover, induction of the miR-17-92 cluster in normal thyroid follicular cells strongly impairs thyroid differentiation and induces a pro-oncogenic effect by blocking TGF- $\beta$ signaling and increasing cell migration.

Conclusions: miR-17-92 is a potent regulator of thyroid follicular cell differentiation, and CRISPR/Cas9nmediated editing of the miR-17-92 gene efficiently blocks $m i R-17-92$ expression in the KTC2 ATC cell line, resulting in improvement of thyroid differentiation. Thus, targeting miR-17-92 could provide a potential molecular approach to restoring thyroid cell differentiation and NIS expression in aggressive thyroid cancer.
\end{abstract}

Keywords: microRNAs, miR-17-92, thyroid cancer, differentiation, CRISPR/Cas9n

\section{Introduction}

$\mathbf{T}$

HYROID CANCER Is the most frequent endocrine cancer and the most rapidly increasing cancer in incidence (1). Thyroid oncogenesis is mediated mainly by genetic alterations in MAPK signaling, with RET/papillary thyroid cancer (PTC) rearrangements, as well as RAS and BRAF mutations as the most prevalent alterations in PTC $(2,3)$. Anaplastic thyroid cancer (ATC) is the most aggressive histotype of thyroid malignancy, and its pathogenesis remains incompletely un- derstood. High-throughput next-generation sequencing data support a model of multistep carcinogenesis with ATC developing from well-differentiated tumors (4), and the main genetic alterations detected in ATC comprise TP53, BRAF, and TERT mutations (5-8). Nevertheless, most ATC cases are fatal due to the rapidly progressing tumors that become unresectable, refractory to radioiodine therapy, and that develop metastatic disease. Remarkably, recent studies described impressive results in the treatment of a $\mathrm{BRAF}^{\mathrm{V} 600 \mathrm{E}}$ advanced ATC with a neoadjuvant combined therapy of BRAF + MEK

Department of Cell and Developmental Biology, Institute of Biomedical Sciences, University of São Paulo, São Paulo, Brazil. 
inhibitors (dabrafenib + trametinib) and immunotherapy that turned the tumor resectable, and treatable with chemoradiation and sustained control with BRAF therapy in combination with immunotherapy $(9,10)$. Indeed, the combined therapy of dabrafenib + trametinib has been recently approved by the Food and Drug Administration for the treatment of patients with locally advanced or metastatic ATC positive for the $\mathrm{BRAF}^{\mathrm{V} 600 \mathrm{E}}$ mutation and with no satisfactory locoregional treatment options.

MicroRNAs (miRNAs), small noncoding RNAs ( $22 \mathrm{nt}$ ), have been recognized as potent regulators of gene expression; they target post-transcriptional regulation of messenger RNAs (mRNAs), modulating the vast majority of processes that contribute to tumorigenesis and progression. miRNA deregulation is one of the hallmarks of cancer (11), and high levels of the miR-17-92 cluster have been detected in ATC (12). The miR-17-92 cluster, also known as oncomiR-1, transcribes seven mature miRNAs ( $m i R-17-5 p, m i R-17-3 p$, $m i R-18 a, m i R-19 a, m i R-20 a, m i R-19 b$, and $m i R-92 a)$ that ultimately exert a pro-oncogenic effect in various types of cancers (13-15). High-throughput miRNA expression studies have shown increased expression of $m i R-17-92$ in PTC (16), and our group showed that $\mathrm{BRAF}^{\mathrm{V} 600 \mathrm{E}}$ activates the $m i R-17$ 92 cluster in normal thyroid follicular cells (17). The $\mathrm{BRAF}^{\mathrm{V} 600 \mathrm{E}}$ oncogene is associated with a loss of expression of the sodium iodide symporter (NIS/SLC5A5) and induces genomic instability in normal thyroid follicular cells (18), thus contributing to refractoriness to radioiodine therapy and disease progression, as observed in the aggressive subtypes of PTC and ATC (19). An in silico search showed that miRNAs can potentially target genes involved in thyroid cell differentiation (e.g., PAX8) and various components involved in thyroid hormone synthesis including NIS and thyroperoxidase (TPO) (20).

Investigating the role of miR-17-92 could improve the understanding of thyroid cancer aggressiveness due to loss of differentiation. In this study, we demonstrate that CRISPR/ Cas9n gene editing of the miR-17-92 cluster results in promotion of thyroid follicular cell differentiation by increasing the expression of NIS, TPO, thyroglobulin (TG), PAX8, and NKX2-1 (previously known as TTF1) in the KTC2 ATC cell line, while inhibiting cell migration and proliferation by restoring transforming growth factor beta (TGF- $\beta$ ) signaling pathway responsiveness. Moreover, induction of the miR-17-92 cluster in normal thyroid follicular cells strongly impaired thyroid differentiation and induced a pro-oncogenic effect. Thus, $m i R-17-92$ plays an important role in thyroid biology and differentiation, and modulating this cluster of miRNAs could improve thyroid cancer differentiation and cancer management.

\section{Methods}

\section{Cell lines and culture}

The human ATC cell line KTC2 was cultivated in RPMI supplemented with $5 \%$ fetal bovine serum (FBS). Stable KTC2 clones with miR-17-92 cluster gene edited by CRISPR/ Cas9n (named as KTC2-Cl) were constructed according to the protocol of the laboratory of Ran et al. $(21,22)$ by co-transfection of two plasmids containing guide RNAs (gRNAs) designed using the CRISPR Design website (http:// crispr.mit.edu). The gRNAs, gRNA-A and gRNA-B, were designed to target two regions of the miR-17-92 cluster in
MIR17HG (miR-17-92 host gene) at chromosome 13 (Supplementary Table S1). The gRNA-A targets the region -24 nucleotides upstream of the precursor of pre-mir-17, and guide $\mathrm{B}$ targets the region +30 nucleotides inside pre-mir-17 (Fig. 1). The gRNA-A and gRNA-B were cloned at the $B b s I$ site downstream U6 promoter in the plasmids pSpCas9n(BB)-2A-PURO (PX462) and pSp-Cas9n(BB)-2A-GFP (PX461) (Addgene, Watertown, MA), respectively (Supplementary Table S2).

Genomic DNA was used to amplify an 800 bp target segment surrounding the gRNAs target site in the miR-17-92 gene with specific primers (Surveyor primers) (Supplementary Table S1), and the Surveyor ${ }^{\circledR}$ Mutation Detection Kit (Integrated DNA Technologies, Skokie, IL) was used to confirm successful gene editing (mismatch) in the clones (Supplementary Fig. S1). GFP positive + puromycin-resistant single cell clones were expanded, and gDNA was extracted for sequencing confirmation after cloning the polymerase chain reaction (PCR) product into pGEM-T-easy (Promega, Madison, WI).

The rat PCC13 thyroid follicular cell line was cultivated in F-12 Coon's modified medium (Sigma, St. Louis, MO) supplemented with 5\% FBS and four hormones and maintained at $37^{\circ} \mathrm{C}$ and $5 \%$ carbon dioxide $\left(\mathrm{CO}_{2}\right)$, as described previously (17). We transfected $\mathrm{PCCl} 3$ cells with different plasmids (Supplementary Table S2) to generate stable cell lines with expression of the whole cluster (PCCl3-miR-17-92), $m i R-17$ (PCCl3-miR-17), miR-19b (PCCl3-miR-19b), miR$20 a$ (PCCl3-miR-20a), miR-92 (PCCl3-miR-92a), and the segment with miR-19a/miR-20a/miR/19b (PCCl3-miR-19a/ miR-20a/miR-19b). As control, we transfected PCCl3 cells with empty plasmid (PCCl3-Ø).

\section{Cell function assays}

Cell counting. Growth curves were determined using KTC2 cells by seeding $2 \times 10^{4}$ cells per well in 6-well plates and cultivation for $24-72$ hours. TGF- $\beta 1$ responsiveness was analyzed by seeding $5 \times 10^{4} \mathrm{KTC} 2$ cells per well in 6 -well plates. After 12 hours of adherence, cells received one pulse of recombinant TGF- $\beta 1$ (rTGF- $\beta 1)(5 \mathrm{ng} / \mathrm{mL})$ (rTGF- $\beta 1$; Peprotech, Rocky Hill, NJ) in the culture medium. Cells were detached by trypsinization after 48 hours and counted in a Guava minicytometer (Millipore, Burlington, MA). Highconcentration iodine treatment in $\mathrm{PCCl} 3$ cells was performed by diluting a $1 \mathrm{M}$ stock solution of sodium iodide ( $\mathrm{NaI})$ in the medium to reach $10^{-3} \mathrm{M}$, and cell counting was performed after 24 hours of iodine treatment.

Cell viability assay (MTT). Cells were plated at $2 \times 10^{4}$ cells per well in 96-well plates and cultured for 24 hours. 3(4,5-dimethylthiazol-2-yl)-2,5-diphenyltetrazolium bromide (MTT) was added to the cell culture medium to a final concentration of $250 \mu \mathrm{g} / \mathrm{mL}$ and incubated at $37^{\circ} \mathrm{C}$ in $5 \% \mathrm{CO}_{2}$ incubator for 4 hours. Then, the medium was removed and formazan crystals were solubilized with $0.01 \mathrm{M} \mathrm{HCl}$ in isopropanol. Absorbance was measured at $595 \mathrm{~nm}$ in a plate spectrophotometer SpectraMax M (Molecular Devices, San Jose, CA).

Cell cycle. Cells were detached by trypsinization, pelleted with supernatant (dead cells), and fixed with $70 \%$ ethanol. After hydration in phosphate-buffered saline (PBS), 


\section{A}

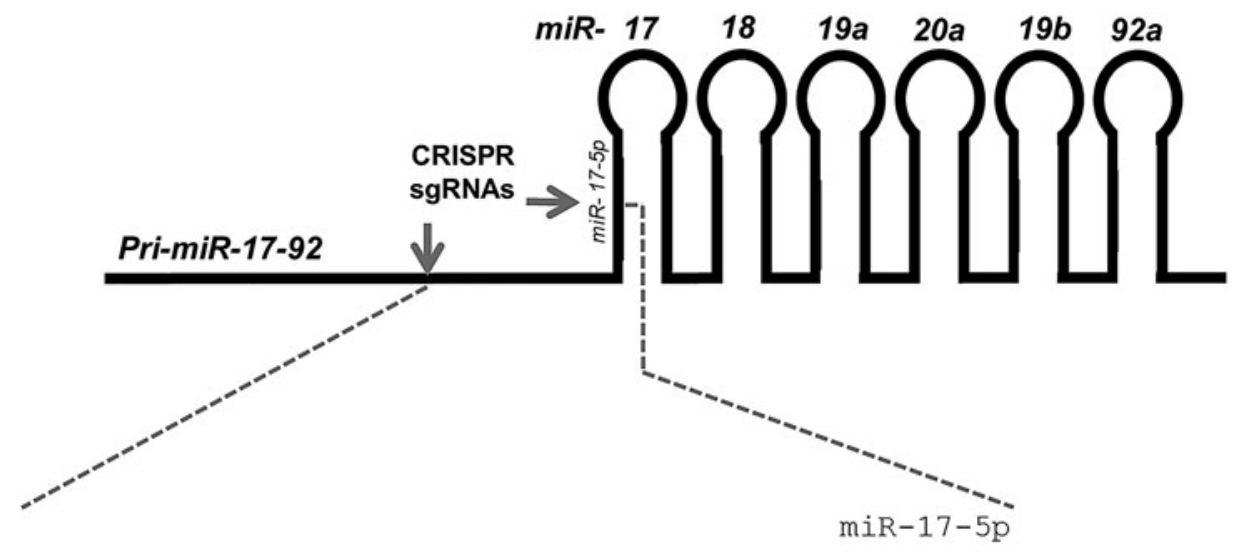

$\begin{array}{rrl}\text { Wt } & \text { ACCTTGTAAAACTGAAGATTGTGACCAGTCAGAATAATGTCAAAGTGCTTACAGTGCAGGTAGTGAT } \\ \text { cl } & 3 & \text { ACCTTGTAAAACTGAAGATTGTGACCAGTCAGAAT-----------ACAGTGCAGGTAGTGAT } \\ \text { c1 } & 1 & \text { ACCTTGTAAAACTGAAGATTGTGACCAGTCAGAATAATGTCATG----TCAAAGTGCAGGTAGTGAT }\end{array}$

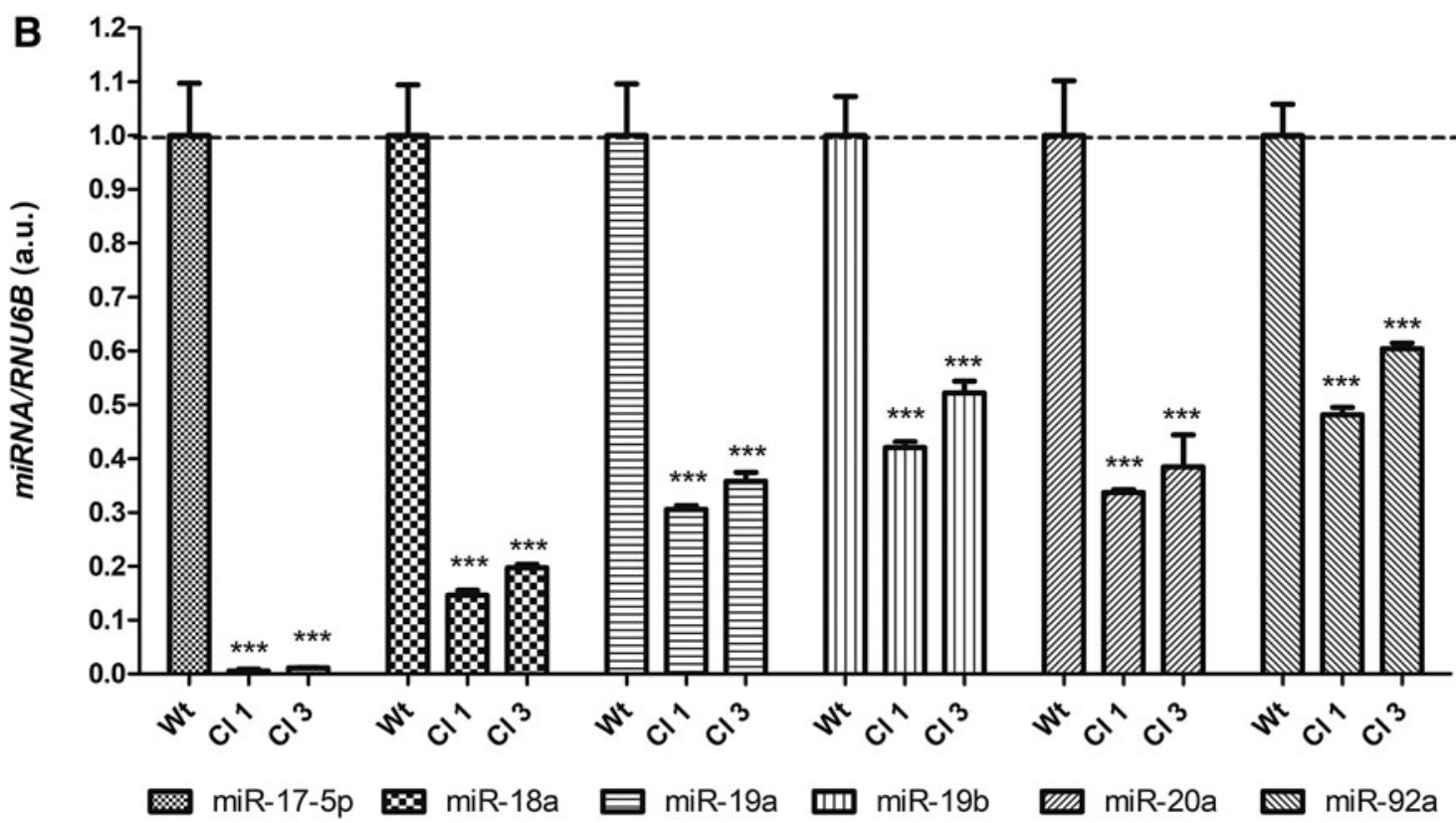

FIG. 1. CRISPR/Cas9n-edited miR-17-92 gene in anaplastic thyroid cancer. (A) Result of genomic DNA sequencing of KTC2 clones 1 and 3 after CRISPR/Cas9n-mediated miR-17-92 gene editing. sgRNA-guided target regions are highlighted in gray. Double nicking and DNA repair resulted in $15 \mathrm{nt}$ deletion in clone $3(\mathrm{Cl} 3)$ and $4 \mathrm{nt}$ deletion $+4 \mathrm{nt}$ changes in clone 1 (C11) $m i R-17-92$ gene. (B) Gene expression validation of $m i R-17-92$ mature miRNAs levels in CRISPR/Cas9n-edited KTC2-Cl1 and KTC2-C13. Data are expressed as mean \pm SD $(n=3)$ for gene expression. $* * * p<0.0001$ versus KTC2-Wt. miRNAs, microRNAs; SD, standard deviation; sgRNA, single guide RNA.

cells were treated with RNase $(100 \mu \mathrm{g} / \mathrm{mL})$ and DNA was stained with propidium iodide $(50 \mu \mathrm{g} / \mathrm{mL})$. The cell cycle was characterized by counting 10,000 events under flow cytometry using Guava EasyCyte Mini (Millipore).

Wound assay. $\quad 1 \times 10^{5}$ cells were plated in 6 -well plates and cultured until confluency. Next, $2 \mu \mathrm{g} / \mathrm{mL}$ mitomycin (Sigma) was added to the medium for 2 hours before performing the scratch in the monolayer using a $100-\mu \mathrm{L}$ tip. After several washes with PBS, the medium was replaced by complete medium containing $2 \mu \mathrm{g} / \mathrm{mL}$ mitomycin (Sigma). Wound closure was monitored until cells completely repopulated the scratch (48 hours) under an inverted micro- scope EVOS XL Core Imaging System (Thermo Fisher Scientific, Waltham, MA).

Transwell assay. A migration assay was performed using uncoated Transwell ${ }^{\mathrm{TM}}$ chambers with membrane pore size of $8.0 \mu \mathrm{m}$ (Corning Inc, Corning, NY). $2 \times 10^{4}$ cells were suspended in culture medium containing $0.5 \%$ FBS and plated in the upper chamber, whereas the lower chamber contained culture medium with $5 \%$ FBS. The cells that migrated through the membrane within 24 hours were fixed in $4 \%$ paraformaldehyde diluted in PBS and stained with $0.5 \%$ crystal violet. Cells were photographed using a Nikon Eclipse 
E600 microscope equipped with a CF160 epi-fluorescence optical camera and counted (10 representative fields).

\section{Gene expression by quantitative PCR}

Total RNA was extracted using the phenol-chloroform method using the TRIzol reagent (Invitrogen-Thermo Fisher, Carlsbad, CA). Protein coding gene expression was investigated using complementary DNA (cDNA) generated from the reverse transcription of $1 \mu \mathrm{g}$ of total RNA using oligo-dT primer and MMLV reverse transcriptase (Invitrogen-Thermo Fisher). Quantitative PCR was performed in a ViiA7 ${ }^{\circledR}$ Sequence Detection System (Applied Biosystems-Thermo Fisher, Foster City, CA) using SYBR Green Master Mix, cDNA, and specific primers (Supplementary Table S1). Gene expression was normalized by comparison with Rpl19 levels and calculated using the QGene program (23).

For miRNA expression, $10 \mathrm{ng}$ of total RNA was reverse transcribed using a TaqMan ${ }^{\circledR}$ Reverse Transcription Kit (Applied Biosystems-Thermo Fisher) in the presence of stem-loop primers, followed by quantitative PCR using TaqMan MicroRNA Assays for $m i R-17-5 p$ (assay 393), $m i R$ $18 a-5 p$ (assay 2422), miR-19a-3p (assay 395), $m i R-19 b-3 p$ (assay 396), miR-20a-5p (assay 580), miR-92a-3p (assay 430), small nucleolar RNA (snoRNA) (assay 1718), and RNU6B (assay 1093) (Applied Biosystems-Thermo Fisher), and TaqMan Universal PCR Master Mix, No AmpErase ${ }^{\circledR}$ UNG (Life Technologies-Thermo Fisher, Carlsbad, CA) in a ViiA7 Sequence Detection System. Gene expression was normalized by comparison to snoRNA levels and calculated using the QGene program (23).

\section{Western blotting analyses}

Total protein was extracted from cells using RIPA buffer (20 mM Tris, pH 7.5, $150 \mathrm{mM} \mathrm{NaCl,} \mathrm{1 \%} \mathrm{Nonidet} \mathrm{P-40,} \mathrm{0.5 \%}$ sodium deoxycholate, $1 \mathrm{mM}$ EDTA, and $0.1 \% \mathrm{SDS}$ ) containing $10 \%$ protease inhibitor cocktail (Sigma). Protein concentration was determined using the Bradford assay (BioRad Laboratories, Hercules, CA), and $40 \mu \mathrm{g}$ of each sample was fractionated by $10 \%$ SDS-PAGE and blotted onto a nitrocellulose Hybond-ECL membrane (Amersham Biosciences, Little Chalfont, UK). Nonspecific binding sites were blocked with $5 \%$ nonfat dry milk in Tris-buffered saline- $0.1 \%$ Tween20. The following primary antibodies were used: mouse anti-SMAD4 (sc-7866), rabbit anti-TGFBRII (sc-220), rabbit anti-TTF1 (sc-13040), mouse anti-PAX8 (sc-81353), rabbit anti-cMYC (sc-764), rabbit anti pSMAD3 (sc-130218), mouse anti- $\alpha$-tubulin (sc-5286), mouse anti- $\beta$-actin (sc-47778), mouse anti-vimentin (sc-32322) (Santa Cruz, Santa Cruz, CA), and rabbit anti-LIN28B (Cell Signaling, Danvers, MA). The rabbit anti-NIS antibody was kindly donated by Dr. Sissy Jhiang. Antibody bound to target protein was detected with horseradish peroxidase-conjugated secondary antibodies and developed with luminol and p-coumaric acid (Sigma) reagents in the presence of hydrogen peroxide. Chemiluminescence emission was visualized with a ImageQuant LAS4000 imaging system (GE Healthcare, Little Chalfont, UK).

\section{Bioinformatics and luciferase assay}

miR-17 and miR-20 target validation. A segment of the rat Pax8 and human PAX8 $3^{\prime}$-untranslated region (UTR) containing the predicted site $m i R-17 / m i R-20$ (position 10791085 in rat and position 1990-1997 in human mRNA) extracted from TargetScan database (24) was cloned into pmiR-Glo plasmids (Promega) according to the manufacturer's instructions. Briefly, to generate the wild-type (Wt) $m i R-17 / 20$ binding site reporter plasmid (pmiR-Glo-Pax8-Wt), two oligonucleotides were annealed and ligated in pmiR-Glo digested with $X h o I$ and $X b a I$. As control, we also generated mutated plasmids that contained mutations in the seed sequence of miRNA binding sites (pmiR-Glo-Pax8-mut) that would block miRNA interaction. We also constructed a $m i R$ 19 and a miR-17/20 pmiR-Glo plasmid to test DICER1 as potential target (Supplementary Table S1). Transient transfection of pmiR-Glo-Pax8-Wt and pmiR-Glo-Pax8-mut was performed in PCCl-miR-17, PCCl3-miR-20a, and PCCl3miR-19b cells. Forty-eight hours after transfection, cell lysates were collected and firefly luciferase activity was measured in a SpectraMax L Luminometer (Molecular Devices) using a Dual Luciferase ${ }^{\circledR}$ Reporter assay system (Promega). Luminescence was normalized by Renilla luciferase levels.

Nis, Tg, and Tpo promoter activity. For this luciferase reporter assay, we used the following plasmids: pNIS-2.8 (25) plasmid contains the 2854-bp fragment of the rat Nis promoter; pGL-Tg (26) contains a 202-bp fragment of the human $T G$ promoter, and pTPO-luc contains a 420-bp fragment of the human TPO promoter (27). Three hundred nanograms of pNIS 2.8, pGL-Tg, or pTPO-luc plasmids was co-transfected with $30 \mathrm{ng}$ of Renilla pRL plasmid as control for transfection efficiency using Lipofectamine 3000 (Life Technologies-Thermo Fisher). Cell lysates were collected after 24 hours of transfection. Firefly and Renilla luciferase were measured using the Dual-Luciferase Reporter assay system (Promega) in GloMax ${ }^{\circledR}$ 20/20 Luminometer (Promega).

TGF- $\beta$ signaling activity. To evaluate the responsiveness to TGF- $\beta$ signaling, we used the SBE4 Luc plasmid that contains four copies of the Smad Binding Element (SBE) or a p3TP-lux plasmid (Addgene) (Supplementary Table S2). Briefly, $4 \times 10^{4}$ cells were seeded into 24 -well plates and transfected with $300 \mathrm{ng}$ of SBE4-Luc (or p3TP-lux) plus $30 \mathrm{ng}$ of pRL (Renilla luciferase) using Lipofectamine 2000 (Invitrogen-Thermo Fisher) before the treatment with $1 \mathrm{ng} /$ $\mathrm{mL}(20 \mathrm{U} / \mathrm{mL})$ rTGF- $\beta$ (Peprotech) in culture medium for 24 hours. Cell lysates were collected after 24 hours, and luminescence was measured as described previously. To evaluate the effect of TGFBR2 knockdown on TGF- $\beta$ signaling, we transiently transfected KTC2 cells with a SGEP plasmid containing short hairpin RNA for human TGFBR2 mRNA (Supplementary Table S1) 48 hours before transfection with TGF- $\beta$ reporter plasmid SBE4 luc. Then, cells were treated with $1 \mathrm{ng} / \mathrm{mL}$ TGF- $\beta 1$ for 24 hours, and cell lysates were collected and luminescence was measured as previously described.

\section{Statistical analysis}

The results are presented as the mean \pm standard deviation, and they were submitted to analysis of variance followed by the Tukey test. Differences were considered significant at $p<0.05$. 


\section{Results}

miR-17-92 silencing via CRISPR/Cas9n induces thyroid follicular cell differentiation and restores TGF- $\beta$ antimitogenic response

As miR-17-92 cluster expression is increased in ATC samples (12) and cell lines (Supplementary Fig. S2), we investigated the role of silencing $m i R-17-92$ in thyroid cell function. To that end, we used the CRISPR/Cas9n system to efficiently edit the miR-17-92 gene in the human ATC cell line KTC2 and knock down all the cluster components simultaneously. Using two CRISPR/Cas9n plasmids, we designed two single guide RNAs to target the $5^{\prime}$ region upstream of the miR-17 precursor. This region contains the splicing factor binding site (Fig. 1A) essential for primary miR-17-92 processing into mature miRNAs (28). The edition of the miR-17-92 gene was efficient in ATC cell line KTC2 as observed in genomic DNA sequencing of two clones (KTC2$\mathrm{Cl1}$ and $\mathrm{KTC} 2-\mathrm{Cl} 3$ ) (Fig. 1A). The gene editing resulted in global downregulation of miR-17-92 mature miRNA levels, ranging from $>90 \%$ inhibition of $\mathrm{miR}-17-5 \mathrm{p}$ to $>40 \%$ inhibition for miR-92a (Fig. 1B).

After this initial validation of the system, we evaluated expression of thyroid differentiation genes in response to miR-17-92 silencing by CRISPR/Cas9n. We observed an increase in the gene expression of NIS, TPO, TG, and the transcription factors $P A X 8$ and $N K X 2-1$ in KTC2-Cl1 and KTC2-Cl3 (Fig. 2A). NIS mRNA expression was detected at very low levels that increased after $m i R-17-92$ silencing. Accordingly, protein expression of PAX8 and NKX2-1 was increased in KTC2-Cl1 and $\mathrm{KTC} 2-\mathrm{Cl} 3$ analyzed by Western blot (WB) (Fig. 2B). However, NIS and TPO protein were undetectable by WB and immunofluorescence (data not shown).

Next, we used the luciferase reporter plasmids pNis 2.8, pGL-Tg, and Tpo-luc to investigate promoter activity of the NIS (SLC5A5), TG, and TPO genes, respectively. We observed a strong induction of $T G$ and $T P O$ promoters in $m i R$ 17-92 CRISPR/Cas9n-edited KTC2-Cl1 and KTC2-Cl3, while interestingly NIS gene promoter activity was reduced compared with KTC2-Wt cells (Fig. 2C).

Functionally, targeting $m i R-17-92$ by CRISPR/Cas9n exerted an antitumorigenic effect in KTC2 cells. We observed a reduced cell count of $\mathrm{KTC} 2-\mathrm{Cl} 1$ and $\mathrm{KTC} 2-\mathrm{Cl} 3$ clones compared with KTC2-Wt cells (Fig. 3A). Moreover, cell colony formation (Fig. 3B) and cell migration (in the presence of mitomycin) (Fig. 3C) were strongly repressed in KTC2-Cl1 and KTC2-Cl3 clones, leading us to investigate TGF- $\beta$ signaling, an important antiproliferative pathway for thyroid cells. We observed increased protein levels of the TGF- $\beta$ signaling components TGFBR2 and SMAD4 (Fig. 3D), both validated targets of miR-17-92 $(17,29)$, in KTC2-Cl1 and KTC2-Cl3 clones compared with KTC2-Wt cells. Interestingly, MYC protein levels were reduced in KTC2-Cl1 and KTC2-Cl3 clones (Fig. 3D). MYC is a known positive regulator of $m i R-17-92$ (30) and is repressed by TGF- $\beta$ signaling activation (31).

To evaluate whether TGF- $\beta$ signaling responsiveness was altered in KTC2 clones after $m i R-17-92$ edition, we performed cell counting in the presence of recombinant active TGF- $\beta 1$ and observed that KTC2-Cl1 and KTC2-Cl3 showed recovery of the antimitogenic response to TGF- $\beta 1$ treatment leading to reduction in cell number, an effect not observed in
KTC2-Wt cells (Fig. 3E). Indeed, KTC2-Cl1 and KTC2-Cl3 showed high basal levels of pSMAD3 nuclear staining compared with KTC2-Wt indicating a reactivation of TGF- $\beta$ signaling in these cells (Fig. 3F). This finding was further confirmed by a SBE4 luciferase reporter assay that showed a $60 \%$ and $80 \%$ higher response after recombinant TGF- $\beta 1$ treatment in KTC2-Cl1 and $\mathrm{KTC} 2-\mathrm{Cl} 3$, respectively, compared with KTC2-Wt cells (Fig. 3G).

\section{miR-17-92 overexpression impairs TGF- $\beta$ signaling in normal thyroid follicular cells}

To investigate the role of $m i R-17-92$ in normal thyroid cell biology, we overexpressed the miR-17-92 cluster in normal rat thyroid follicular cells $\mathrm{PCCl} 3$ (stable cell line PCCl3miR-17-92) (Fig. 4A). miR-17-92 overexpression increased cell viability measured by MTT (Fig. 4B) and resulted in a fourfold increase in cell migration in $\mathrm{PCCl} 3-m i R-17-92$ cells evaluated by a transwell assay (Fig. 4C), although the cell count was not significantly altered (data not shown).

As $m i R-17-92$ targets are enriched in the TGF- $\beta$ signaling pathway, we analyzed the protein levels of TGFBR2 and SMAD4 and observed a reduction of TGFBR2 in PCCl3$m i R-17-92$ (Fig. 4D). To investigate whether TGFBR2 reduction would impact TGF- $\beta$ signaling, we used a 3TP-lux luciferase reporter assay to evaluate TGF- $\beta$ responsiveness. We observed that the treatment of control PCCl3- $\varnothing$ cells with recombinant active TGF- $\beta 1$ resulted in a dose-dependent increment in luciferase reporter activity (Fig. 4E). However, this effect was significantly reduced by $m i R-17-92$ overexpression in PCCl3-miR-17-92 cells (Fig. 4F). Moreover, TGF- $\beta 1$ treatment resulted in a smaller reduction in cell counting for PCCl3-miR-17-92 cells compared with control PCCl3- $\varnothing$ (Fig. 4F). The analysis of the cell cycle showed that TGF- $\beta 1$ treatment in PCCl3-miR-17-92 cells does not induce G1-cell cycle arrest as observed in PCCl3- $\varnothing$ cells (Fig. 4G).

To further evaluate the role of $m i R-17-92$ in TGF- $\beta$ signaling, we next tested the effect of a high iodine concentration on the cell count of PCCl3-miR-17-92 cells. High iodine induces an antiproliferative effect that is dependent on the activation of the TGF- $\beta$ pathway (32). We observed that high iodine concentration $\left(10^{-3} \mathrm{MNaI}\right)$ decreased the cell count in control cells $(\mathrm{PCCl} 3-\phi)$, but this effect was attenuated after overexpression of miR-17-92 in PCCl3-miR-17-92 cells (Fig. 4H). Next, we investigated the influence of NIS in this effect as this protein is essential to iodine trapping in thyroid follicular cells. Surprisingly, Western blotting showed that PCCl3-miR-17-92 cell exhibited reduced NIS levels (Fig. 4I) that could contribute to the refractoriness to high iodine treatment. Altogether, these results show that $m i R-17-92$ activation in normal thyroid follicular cells exerts a pro-proliferative effect by blunting TGF- $\beta$ signaling responsiveness.

\section{miR-17-92 overexpression impairs thyroid follicular cell differentiation in normal thyroid follicular cells}

The expression analysis of genes involved in thyroid differentiation showed that overexpression of $m i R-17-92$ severely repressed Nis and Tpo gene expression, which are related to iodine metabolism, as well as the thyroid transcription factors $N k x 2-1$ and Pax8 in PCCl3-miR-17-92 cells (Fig. 5A). The analysis of Nis (Slc5a5) and Tg promoter activity using a luciferase reporter assay showed that the Nis 

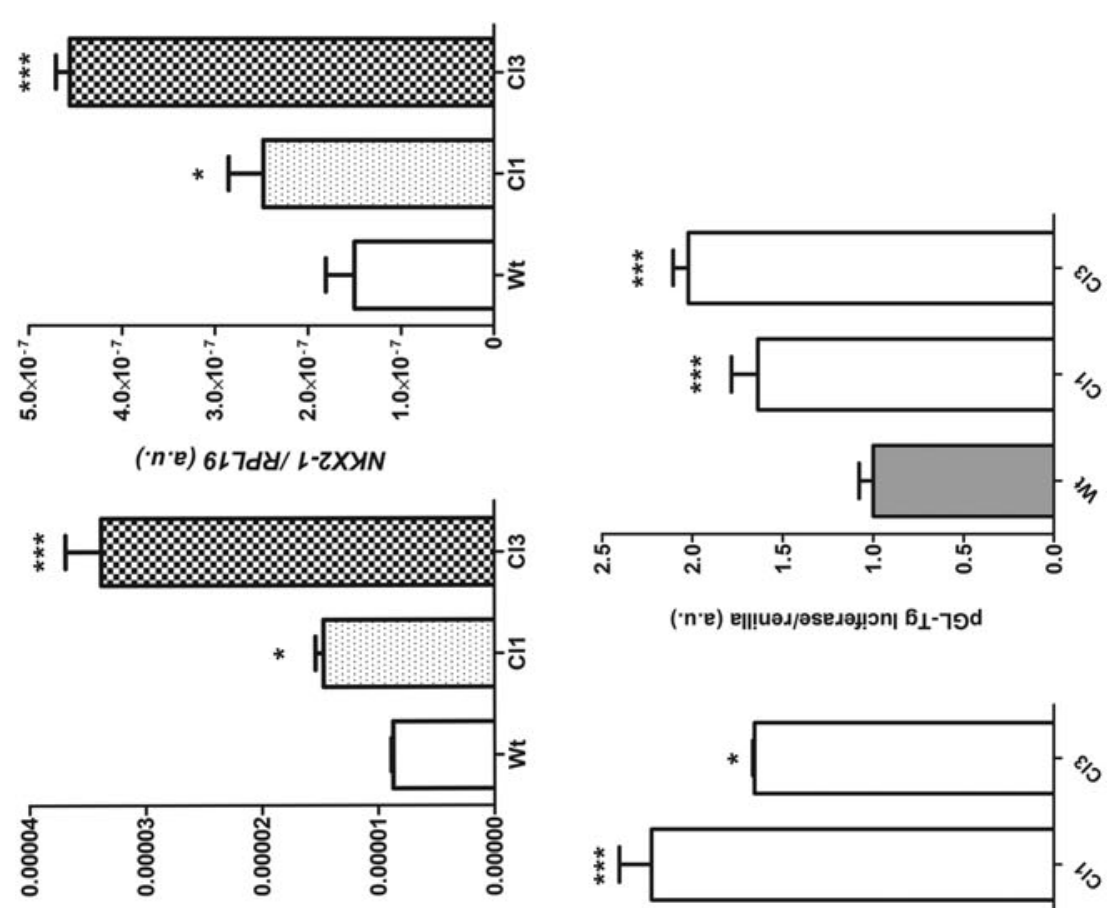

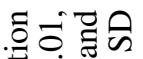

응

苂 㐘

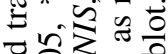

สํํ월

$0 *$ 造造

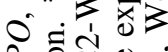

₹.워

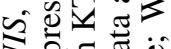

之

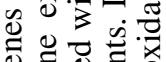

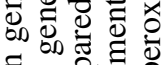

.

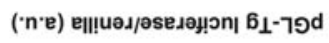

กิm

¿ $\| \overline{0}$

ङ

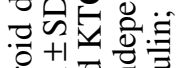

을.

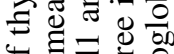

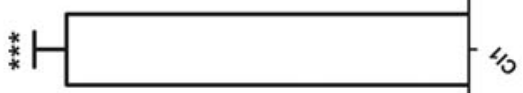

记

อี 닝

('n'e) $6\llcorner 7 d d / 8 X \forall d$

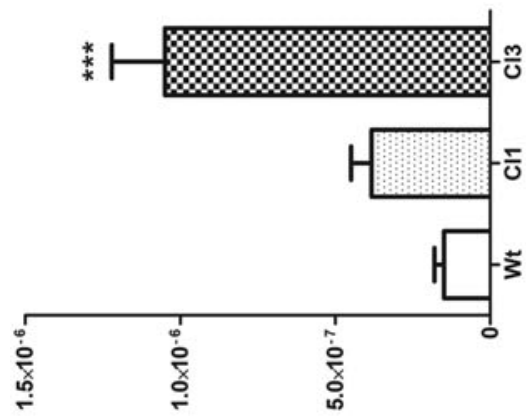

('n'e) $6\llcorner 7 d d / 9 \perp$
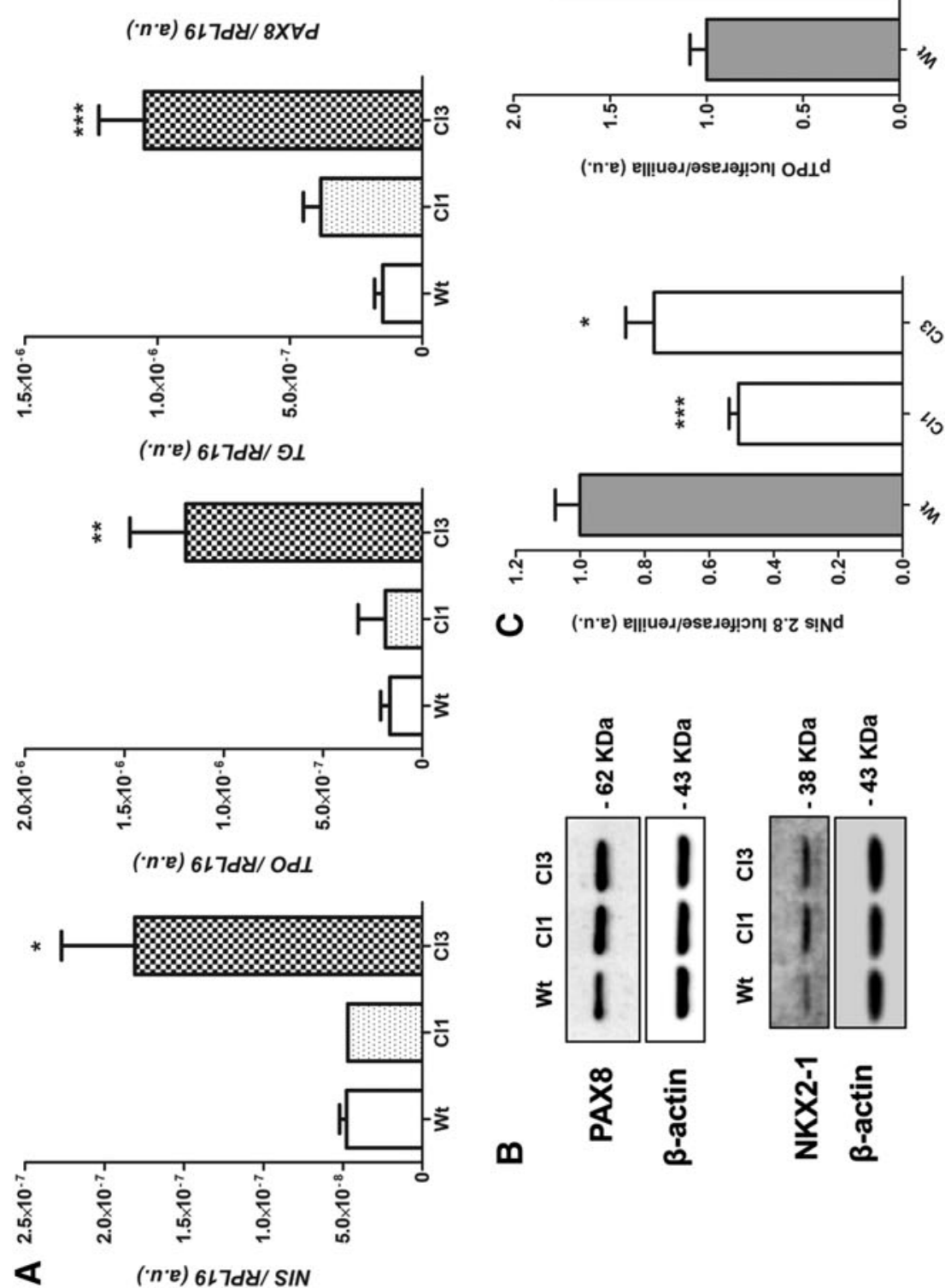

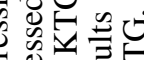

远.

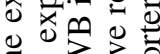

ปั่

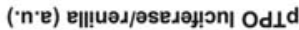

《芯的究

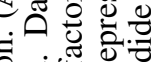

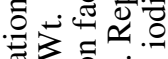

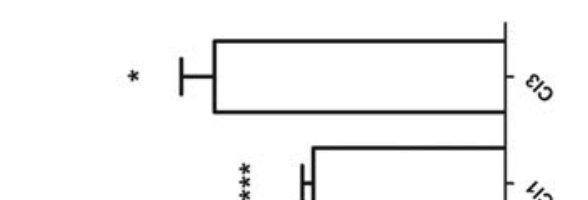

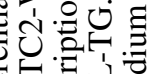

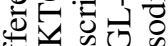

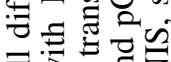

$\overline{\overline{8}}=\overline{\mathrm{Z}}$

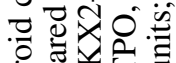
言员员

ฮ 융

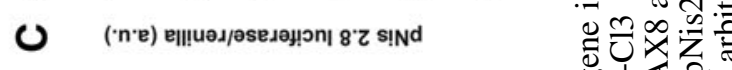

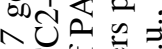

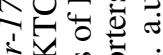

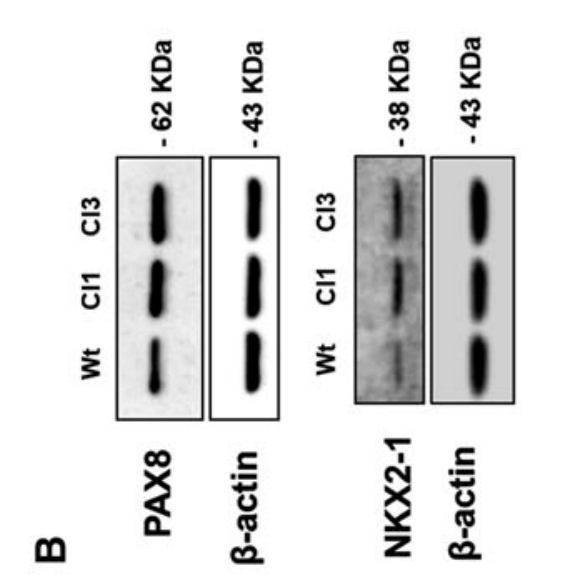

इ⿻一𠃋十

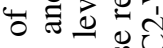

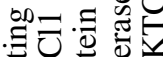

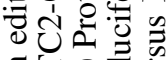

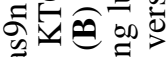

Uึ.

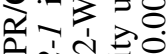

๘ิ่ป

존둔

记羊志*

บู สิ

出

र 0 \&*

ㄱ.

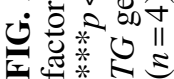



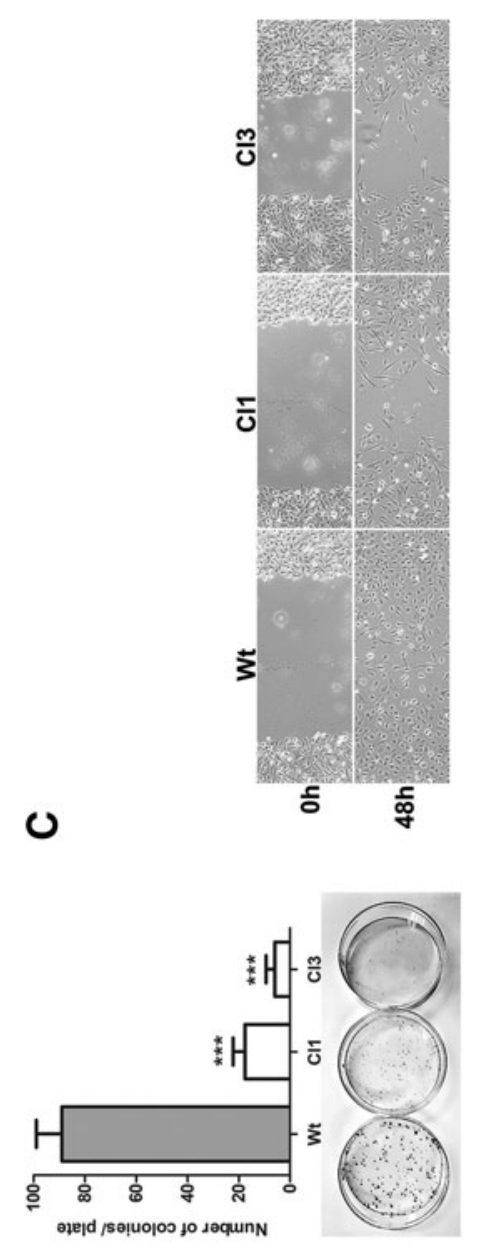

m

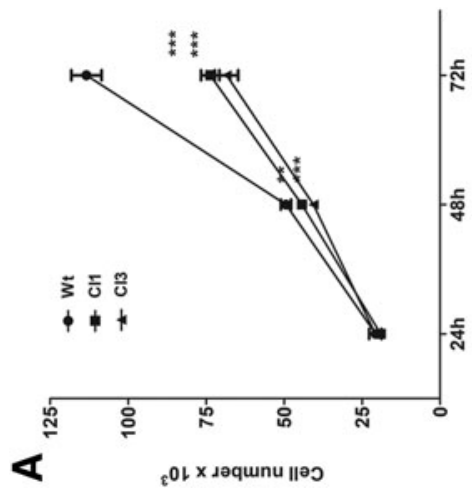

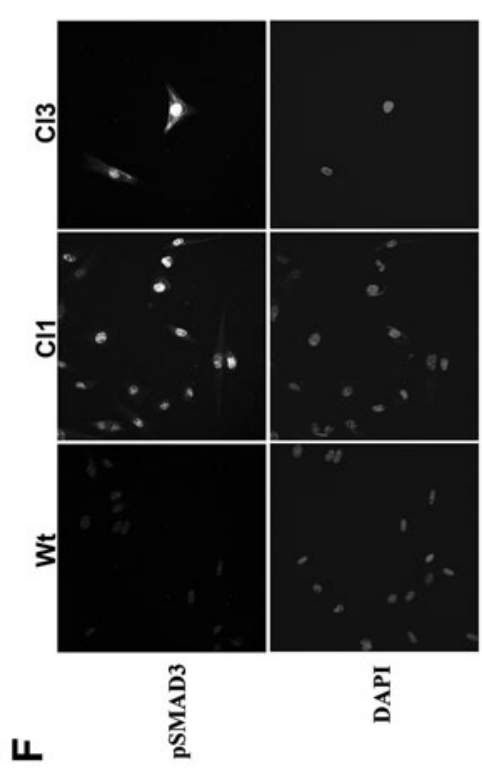

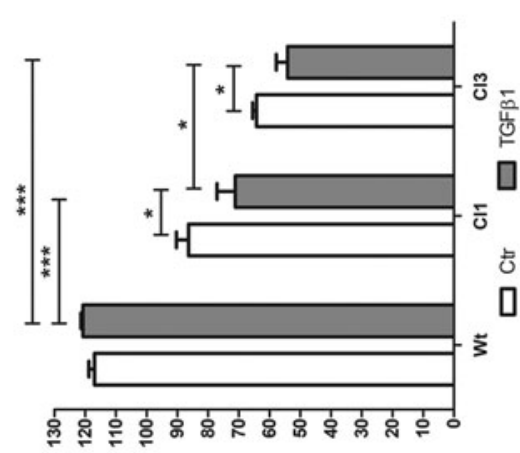

ш

ع 0 X $x$ sequnu ॥əว

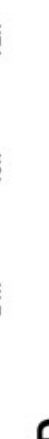

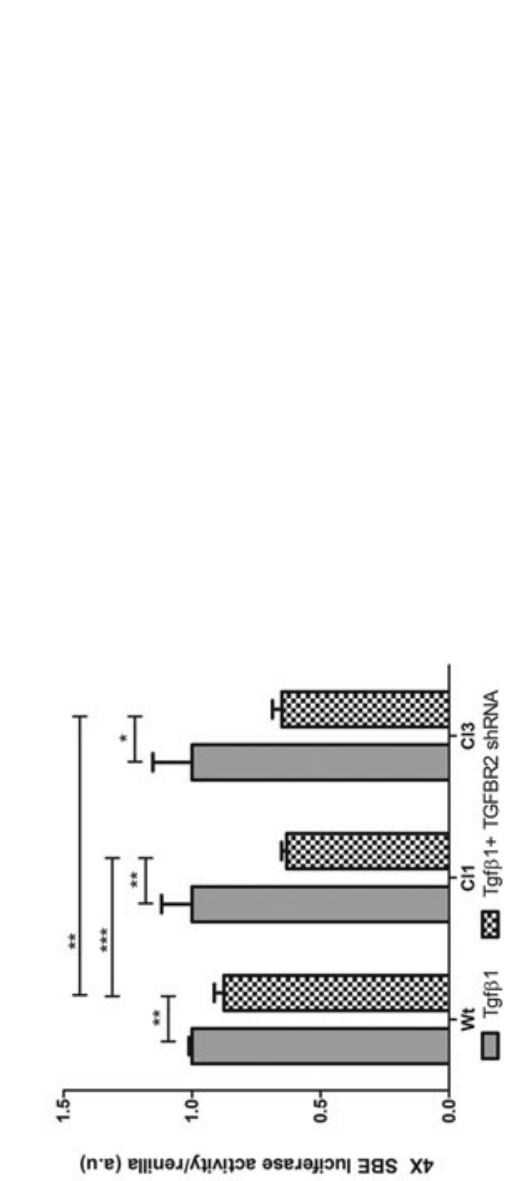

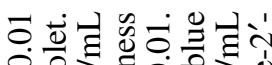
V.ำ * जٓ

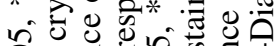
- 0 चै के को 0 政 0 र

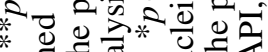

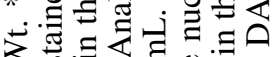

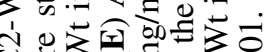
o in 4 U $=\frac{7}{3} \mathrm{~V}$

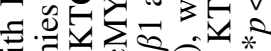
흐의 0

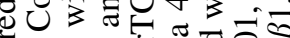

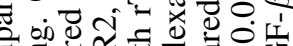
G. क्ष

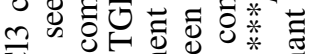

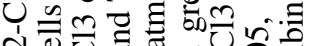
Uู $\forall$ Ưं n

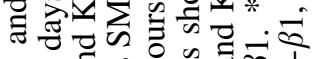

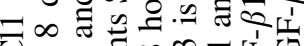
已 Uै

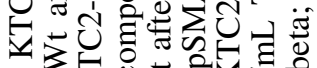

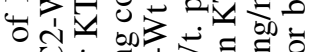
600

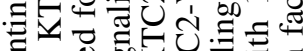
可 으의. वे U छ

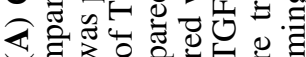

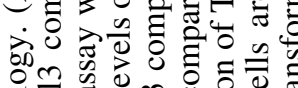
응 0 巻

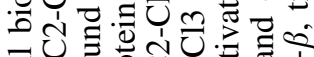
च

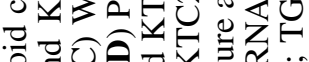

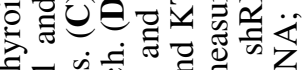
İ

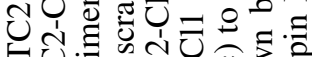

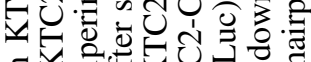

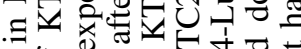

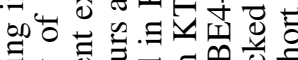
元

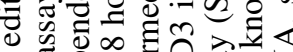

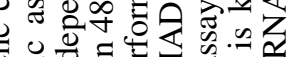

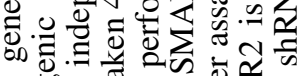

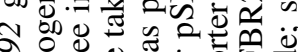

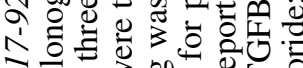

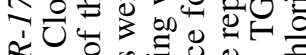
으의

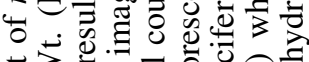

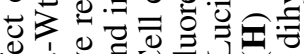

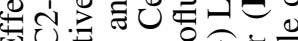

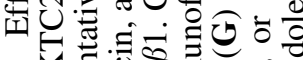

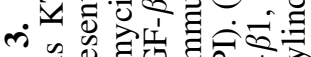
r.

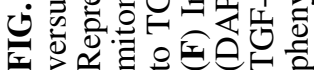


A

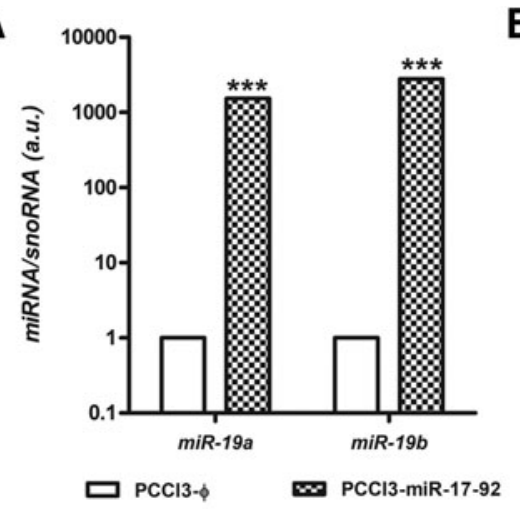

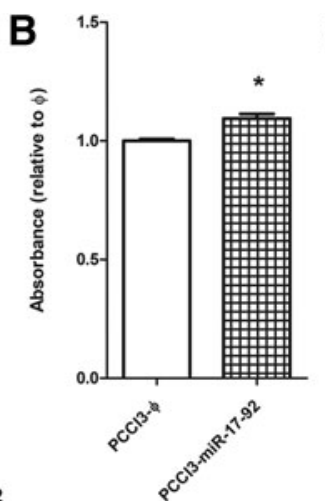
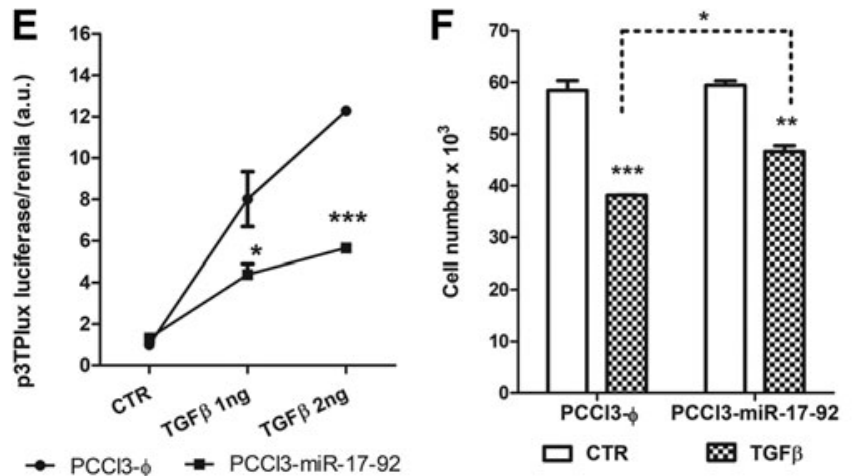

H

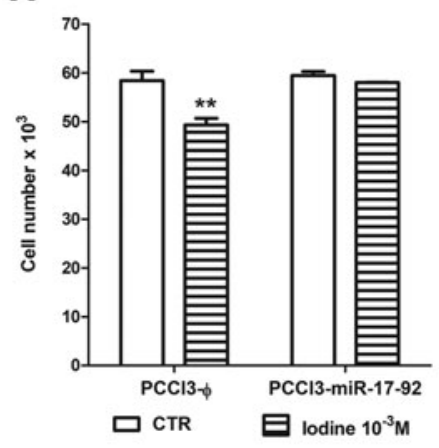

I
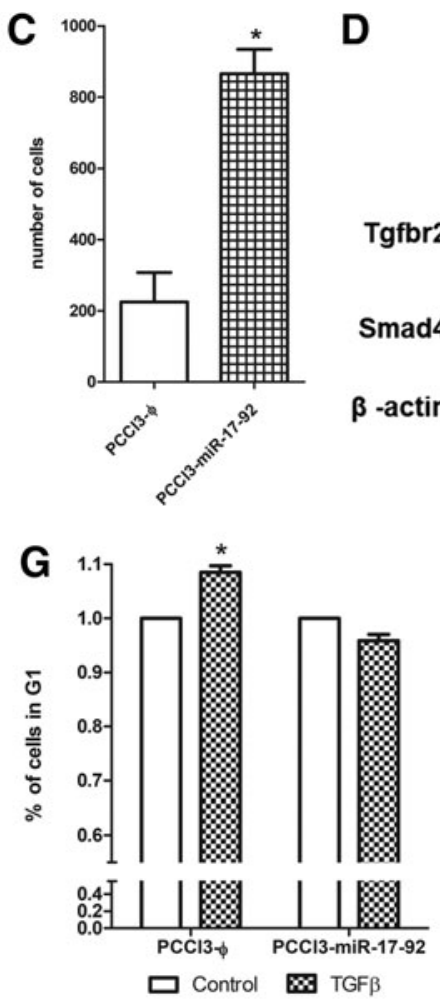
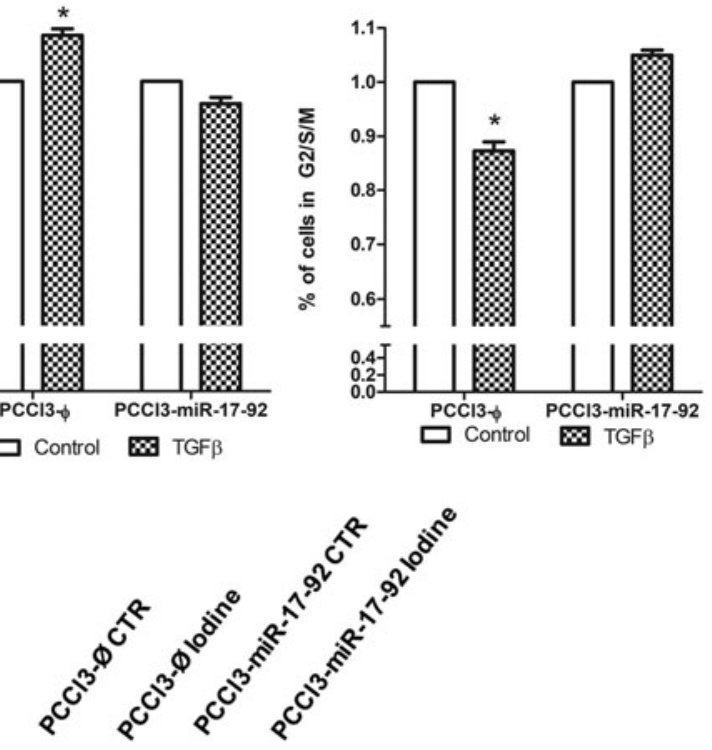

Nis

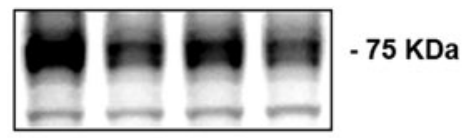

$\beta$-actin

-43 KDa

FIG. 4. Effects of miR-17-92 overexpression in normal rat thyroid follicular cells PCCl3. (A) Validation of miR-17-92 overexpression in PCCl3-miR-17-92 by measuring miR-19a and miR-19b mature miRNA levels. (B) miR-17-92 overexpression increases cell viability measured by MTT assay in PCCl3-miR-17-92 compared with PCCl3- $\phi$. (C) Induces cell migration in a transwell assay. ${ }^{*} p<0.05, * * * p<0.001$ versus $\mathrm{PCCl} 3-\phi$. Representative results of two independent experiments. Data are expressed as mean \pm SD $(n=3)$. (D) Protein levels of TGFBR2 and SMAD4 in PCCl3-miR-17-92 compared with PCCl3- $\phi$ by WB. Overexpression of $m i R-17-92$ in PCCl3 reduces responsiveness to exogenous TGF- $\beta$ treatment. (E) Luciferase assay with 3TP-lux plasmid in the presence of 1 or $2 \mathrm{ng} / \mathrm{mL}$ TGF- $\beta 1$ in PCCl3-miR-17-92 compared with PCCl3- $\phi$. (F) Cell counting and (G) cell cycle analysis 24 hours after $1 \mathrm{ng} / \mathrm{mL}$ TGF- $\beta 1$ treatment in PCCl3-miR-17-92 compared with PCCl3- $\phi$. Representative results of two independent experiments in triplicate. $(\mathbf{H})$ High-iodine concentration $\left(10^{-3} \mathbf{M}\right)$ effect in PCCl3-miR-17-92 cells counting after 48 hours of treatment compared with $\mathrm{PCCl} 3-\phi$. (I) Nis protein expression during high-iodine treatment $\left(10^{-3} \mathrm{M} \mathrm{NaI}\right)$ in PCCl3-miR-17-92 compared with PCCl3- $\phi .{ }^{*} p<0.05$, ** $p<0.01, * * * p<0.001$. Data are expressed as mean \pm SD $(n=3)$. MTT, 3-(4,5-dimethylthiazol-2-yl)-2,5-diphenyltetrazolium bromide; NaI, sodium iodide.

and $T g$ genes are transcriptionally repressed after $m i R-17-92$ overexpression in $\mathrm{PCCl} 3$ cells (Fig. 5B). At the protein level, we also observed an important reduction in NIS and PAX8, while no modulation was observed in NKX2-1. Moreover, $m i R-17-92$ induced the expression of vimentin and LIN28B, markers for mesenchymal cells and stem cells, respectively (Fig. 5C).
miR-17-92 cluster components modulate thyroid differentiation

To dissociate the role of individual miRNAs that comprises the $m i R-17-92$ cluster, we transfected $\mathrm{PCCl} 3$ cells with plasmids to stably express $m i R-17, m i R-19 b, m i R-20 a, m i R-$ $92 a$ individually and the $m i R-19 a / m i R-20 a / m i R-19 b$ cluster 


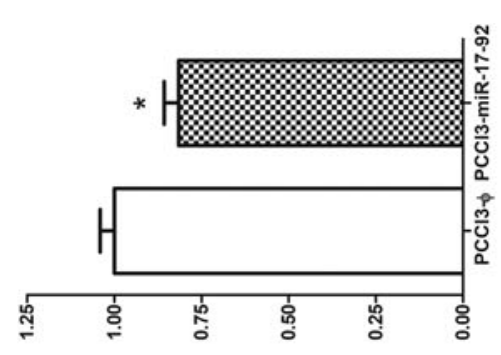

('n'e) $6 L / d y / 8 \times e^{d}$

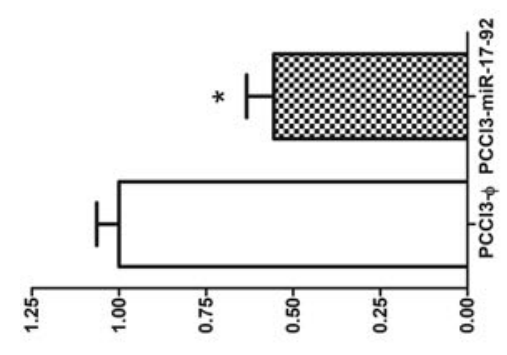

('n'e) $6 L / d y / L-z x / N$

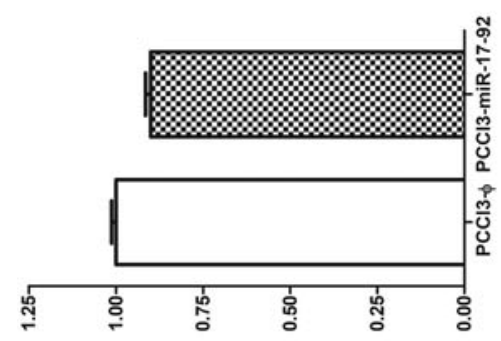

('n'e) 6l/dy/ays $\perp$
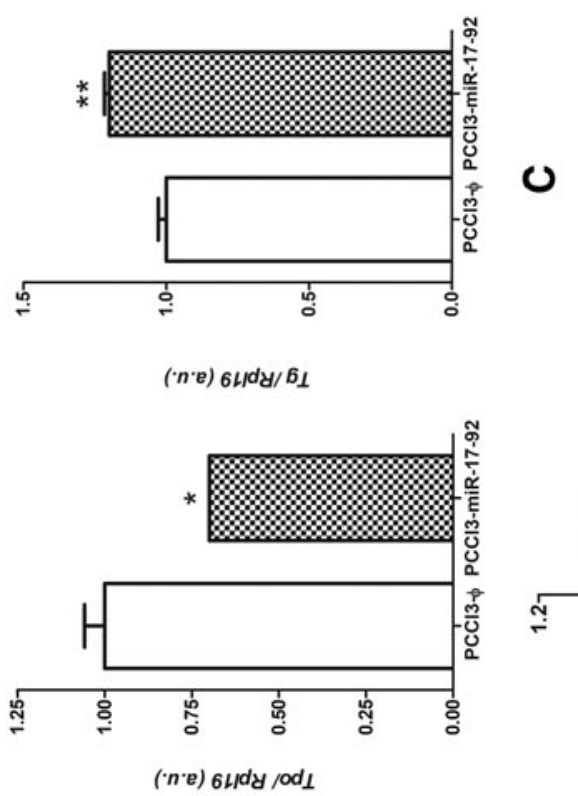

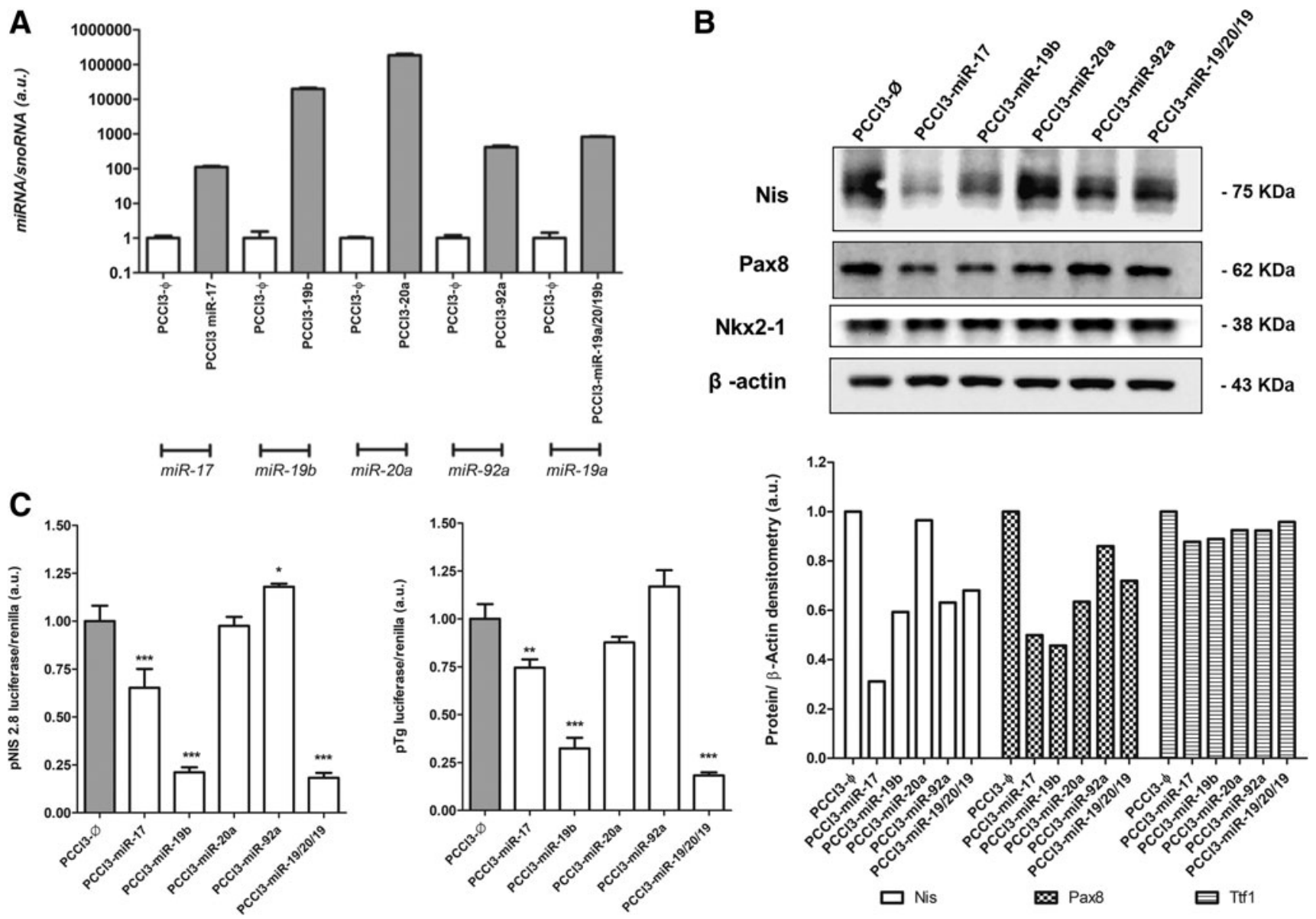

FIG. 6. Overexpression of $m i R-17-92$ cluster components reduces differentiation genes in normal rat thyroid follicular cells. (A) Validation of $m i R-17-92$ cluster components overexpression by qPCR. (B) Protein expression of NIS, PAX8, and NKX2-1 analyzed by WB in PCCl3 overexpressing miR-17-92 components. (C) Nis and Tg promoter activity upon $m i R$-1792 components overexpression. PCCl3 cells were transfected with pNis 2.8 reporter plasmid or pGL-Tg plasmid, and cell lysates were collected after 24 hours. Luciferase levels were normalized by the co-transfection of pRL plasmid that expresses Renilla luciferase gene. ${ }^{*} p<0.05, * * p<0.01$, $* * * p<0.01$ versus PCC13- $\phi$. Representative results of two independent experiments. Data are expressed as mean \pm SD $(n=4)$. qPCR, quantitative polymerase chain reaction; snoRNA, small nucleolar RNA.

as a group (Fig. 6A). We observed that individually $m i R-19 b$, $m i R-92 a$, and $m i R-17$ strongly inhibited the expression of NIS, while miR-20a showed no effect on NIS protein expression (Fig. 6B). Indeed, the combined effect of the whole miR-17-92 cluster components in PCCl3-miR-17-92 resulted in NIS downregulation (Fig. 5C). For the thyroid transcription factor PAX8, we observed that individually $m i R-17$, $m i R-19 b$, and miR-20a inhibited PAX8 protein levels (Fig. 6B) resulting in PAX8 inhibition when the whole $m i R$ 17-92 cluster is overexpressed (Fig. 5C) in $\mathrm{PCCl} 3$ cells. However, the expression of individual or combined $m i R-17$ 92 components did not change NKX2-1 protein levels (Figs. 5C and 6B).

In this context, deregulation of thyroid transcription factor levels could impair NIS protein by influencing the transcriptional activity of the Nis gene. To investigate this possibility, we used the reporter plasmid $\mathrm{pNis} 2.8$ as it contains a $2.8-\mathrm{Kb}$ fragment of the rat Nis gene promoter comprising two PAX8 and one NKX2-1 site (25). Indeed, the activation of the miR-17-92 cluster components lead to transcriptional im- pairment of the Nis gene and a reduction in NIS levels in normal thyroid cells PCCl3 (Fig. 6C). miR-19 expression per se or in combination ( $m i R-19 a / m i R-20 a / m i R-19 b)$, and $m i R$ 17 exerted important repressive effects on Nis gene transcription. For $m i R-20 a$, we did not observe any significant modulation of Nis gene transcription, a result that was confirmed by analyzing NIS expression by WB. Interestingly, miR-92a slightly induced Nis transcriptional activity (Fig. 6C). We observed similar results when analyzing $T g$ promoter activity using a pGL-Tg reporter plasmid in $\mathrm{PCCl} 3$ cells, showing transcriptional inhibition when $m i R-17, m i R-19$ per se, or in combination ( $m i R-19 a / m i R-20 a / m i R-19 b)$ were overexpressed (Fig. 6C). Overall, the expression of the whole $m i R$ 17-92 cluster components leads to transcriptional inhibition of the Nis and $T g$ promoters in normal thyroid follicular cells PCCl3 (Fig. 5B).

These results indicate that miR-17-92 exerts its effects on thyroid differentiation through a common mechanism mediated by thyroid transcription factors. Consequently, we used an in silico approach to search for miR-17-92 cluster 
targets relevant to thyroid cell function. Indeed, analysis with the TargetScan tool revealed that the 3'-UTR segment of rat Pax 8 mRNA contains predicted sites for $m i R-17-5 p$ and $m i R$ $20 a-5 p$. To test the interaction of these miRNAs and Pax8 $3^{\prime}-$ UTR, we constructed a reporter plasmid that contained the Wt sequence of the rat $\operatorname{Pax8} 3^{\prime}$-UTR (position 1079-1085 in the $3^{\prime}$-UTR sequence) predicted to interact with $m i R-17-5 p$ and $m i R-20 a-5 p$, cloned downstream of Luciferase gene in pmiR-Glo plasmid. We also constructed a mutated plasmid (mut) containing mismatches in the region of miRNA/mRNA pairing as control. We transfected these plasmids into $\mathrm{PCCl} 3$ cells overexpressing single components of the cluster, $m i R$ 17, $m i R-20 a$, and $m i R-19 b$ (specificity control) and did not observe a significant downregulation of luciferase activity neither in $m i R$-17-expressing cells nor in $m i R$-20a-expressing cells (data not shown). This result indicates that in this model Pax 8 mRNA is not a target for $m i R-17-5 p / m i R-20 a-5 p$.

Moreover, studies using different mouse models for Dicerl-specific knockout in thyroid follicular cells have shown that miRNAs are necessary to maintain thyroid cell differentiation and function. In these models, loss of DICER1 leads to severe hypothyroidism, and a loss of thyroid cell differentiation and proliferation $(33,34)$. The in silico search also showed that rat Dicerl mRNA 3'-UTR contains one predicted site for an interaction with $m i R-17-5 p / m i R-20-5 p$ and another conserved site for $m i R-19-3 p$. We also constructed a pmiR-Glo plasmid containing the interaction site for $m i R-17-5 p / m i R-20 a-5 p$ (position 2722-2728) and $m i R$ 19-3p (position 1324-1330). However, our results did not show any significant modulation of these Dicerl 3 '-UTR luciferase reporters in response to the modulation of $m i R-17$ 5p/miR-20a-5p and miR-19-3p (data not shown), indicating that in this model, Dicerl mRNA is not a target for these miRNAs.

\section{Discussion}

Overexpression of $m i R-17-92$ is detected in several types of cancers as an important marker of malignancy and tumor aggressiveness $(13,35)$. Indeed, high levels of $m i R-17-92$ are detected in aggressive ATC (12). We show in this study that CRISPR/Cas9n-mediated editing of the $m i R-17-92$ gene is efficient and results in a strong inhibition of $m i R-17-92$ mature miRNAs in the ATC cell line. We designed the gRNAs to target the upstream region of $m i R-17$ pre-miR that contains a splicing site essential for pri-mir-17-92 processing (28). Importantly, we observed a recovery of the expression of the thyroid-specific genes TPO and TG, and to some extent NIS, as well as the PAX8 and NKX2-1 transcription factors. Reestablishing NIS expression is one of the biggest challenges of treating aggressive thyroid cancers. NIS suppression in thyroid cancer is multifactorial and related to epigenetics, transcriptional, and post-transcriptional regulation that involves DNA methylation, MAPK signaling, and miRNAs $(18,36,37)$.

The loss of expression of thyroid differentiation markers related to iodine metabolism is a key event during thyroid oncogenesis and is correlated with aggressive tumor behavior, such as radioiodine refractoriness (RAIR). Ultimately, RAIR is caused by the loss of the iodine-trapping ability mediated by NIS downregulation. Indeed, RAIR thyroid tumors display a high frequency of BRAF mutation and alter- ations in the RAS and PI3K signaling pathways (19). Activation of the BRAF ${ }^{\mathrm{V} 600 \mathrm{E}}$ oncogene is a well-known inhibitor of NIS and thyroid cell differentiation (18). Our group showed recently that the $\mathrm{BRAF}^{\mathrm{V} 600 \mathrm{E}}$ mutation increases $m i R$ 17-92 expression in normal thyroid follicular cells and reduces TGF- $\beta$ signaling responsiveness (17). Moreover, the $\mathrm{BRAF}^{\mathrm{V} 600 \mathrm{E}}$ oncogene can be associated with aggressive clinical-pathological characteristics, such as extrathyroidal invasion, and mortality in thyroid cancers (38-40).

In our study, we show that the activation of the $m i R-17-92$ cluster is an important step to downregulate NIS and thyroid cell differentiation, leading to a loss of iodide uptake in vitro and, hence, expected to be associated with refractoriness to radioiodine in vivo. We dissected the role of individual miRNA components of the miR-17-92 cluster in thyroid differentiation, especially the impact on NIS levels, and observed that while some miRNAs such as $m i R-17-5 p, m i R$ $19 a / b$, and $m i R-92$ may inhibit NIS expression, others such as $m i R-20 a-5 p$ do not modulate NIS levels. Moreover, $m i R-17$, $m i R-19$, and $m i R-20 a$ downregulate the PAX8 transcription factor, indicating that a cooperative targeting of thyroid differentiation genes and transcription factors by the miR-17-92 cluster is a key effect of this oncomiR in thyroid cancer. Taken together, the single components of the miR-17-92 cluster have inhibitory and stimulatory effects in thyroid differentiation, but the overexpression of the whole $m i R-17$ 92 cluster results in an overall inhibitory effect in thyroid follicular cells.

Recently, other miRNAs have been implicated in the regulation of NIS and thyroid differentiation such as $m i R$ $339-5 p$ and $m i R-146 b-3 p(41,42)$. $m i R-339-5 p$ is increased in human PTC and targets the 3 '-UTR of NIS mRNA, and its overexpression efficiently reduces NIS mRNA levels and radioiodine trapping in $\mathrm{PCCl} 3$ and MCF7 cells (41). Moreover, $m i R-146 b-5 p$ is the most overexpressed miRNA in PTC and a hallmark of thyroid cancer, and the $3 \mathrm{p}$ strand $(m i R$ $146 b-3 p$ ) mediates the targeting of NIS and PAX8 mRNAs, leading to the downregulation of thyroid differentiation (42).

In this study, we also show that $m i R-17-92$ activation leads to a loss of responsiveness to the antimitogenic effect of TGF- $\beta$ in normal thyroid cells via deregulation of TGF- $\beta$ signaling components, such as TGFBR2 and SMAD4. In a previous study, we showed that $\mathrm{BRAF}^{\mathrm{V} 600 \mathrm{E}}$ oncogene induces $m i R-19 a / b$ that targets SMAD4 mRNA (17), an effect also observed in SMAD4 when we overexpressed $m i R-19 b$ in $\mathrm{PCCl} 3$ cells (data not shown).

Moreover, silencing of the mature miR-17-92 in KTC2 cells using CRISPR/Cas9n reduced cell counts and increased SMAD4 and TGFBR2 levels, known targets of $m i R-17$ and $m i R-19$ (29), which led to partial restoration of the antimitogenic effect upon rTGF- $\beta 1$ treatment. Interestingly, cMYC protein levels were reduced after miR-17-92 gene silencing. cMYC is one of the transcriptional regulators of $m i R-17-92$ (30), and studies have shown that miR-17-92 cooperates with/mediates MYC effects to promote tumorigenesis $(14,43)$. However, reduction of MYC levels could be associated with the reactivation of TGF- $\beta$ signaling, which has been shown to repress cMYC transcription (31).

In this study, we found a pro-oncogenic role of the $m i R-17$ 92 cluster associated with a loss of differentiation, a loss of NIS expression, and refractoriness to the antiproliferative signal of TGF- $\beta$. By dissecting the cluster into separate 
miRNAs, we demonstrate that $m i R-19, m i R-92$, and $m i R-17$ exert important repressive effects on NIS, NKX2-1, and PAX8 protein levels. Targeting $m i R-17-92$ via CRISPR/ Cas9n gene editing resulted in an effective and stable reduction of mature miR-17-92 and induced a partial restoration of a differentiated phenotype characterized mainly by reestablishing expression of NIS, TG, TPO, PAX8, and NKX2-1. Moreover, it restored TGF- $\beta$ signaling responsiveness in an ATC cell line. The success of CRISPR/Cas9 editing to correct diseases in animal models and its recent success in human embryos (44-46) may ultimately open new perspectives for patients with incurable or aggressive diseases, such as cancer.

\section{Conclusions}

miR-17-92 is a potent regulator of thyroid follicular cell differentiation, and CRISPR/Cas9n-mediated gene editing is efficient to silence $m i R-17-92$ expression in an ATC cell line, resulting in improvement of thyroid differentiation and TGF- $\beta$ antiproliferative response while inducing antitumorigenic effects. Thus, molecular targeting of $m i R-17-92$ could be a potential therapeutic approach for aggressive thyroid carcinomas.

\section{Acknowledgments}

The authors would like to thank the kind donation of KTC2 cells by Dr. Norisato Mitsutake (Nagasaki University Graduate School of Biomedical Sciences, Nagasaki, Japan); donation of the plasmids pNIS 2.8 and pGL-Tg by Dr Pilar Santisteban (Instituto de Investigaciones Biomédicas, CSICUAM, Madrid, Spain) and pTPO-luc by Dr. Samuel Refetoff (The University of Chicago, IL); and donation of NIS antibody by Dr. Sissy M. Jhiang (The Ohio State University, Columbus, $\mathrm{OH})$.

\section{Author Disclosure Statement}

The authors declare that there is no conflict of interest that would impair the impartiality of this article.

\section{Funding Information}

This study was supported by scholarships and grants from Sao Paulo Research Foundation (FAPESP) numbers 2014/50521-0, 2016/17129-4, 2017/01829-0, the National Council for Scientific and Technological Development (CNPq) numbers 308331/2017-6, 151789/2018-5, 430756/2018-6, and University of Sao Paulo, NAPmiR Research Support Center.

\section{Supplementary Material}

Supplementary Figure S1

Supplementary Figure S2

Supplementary Table S1

Supplementary Table S2

\section{References}

1. Siegel RL, Miller KD, Jemal A 2016 Cancer statistics, 2016. CA Cancer J Clin 66:7-30.

2. Kimura ET, Nikiforova MN, Zhu Z, Knauf JA, Nikiforov YE, Fagin JA 2003 High prevalence of BRAF mutations in thyroid cancer: genetic evidence for constitutive activation of the RET/PTC-RAS-BRAF signaling pathway in papillary thyroid carcinoma. Cancer Res 63:1454-1457.

3. Xing M 2013 Molecular pathogenesis and mechanisms of thyroid cancer. Nat Rev Cancer 13:184-199.

4. Landa I, Ibrahimpasic T, Boucai L, Sinha R, Knauf JA, Shah RH, Dogan S, Ricarte-Filho JC, Krishnamoorthy GP, Xu B, Schultz N, Berger MF, Sander C, Taylor BS, Ghossein R, Ganly I, Fagin JA 2016 Genomic and transcriptomic hallmarks of poorly differentiated and anaplastic thyroid cancers. J Clin Invest 126:1052-1066.

5. Nikiforova MN, Kimura ET, Gandhi M, Biddinger PW, Knauf JA, Basolo F, Zhu Z, Giannini R, Salvatore G, Fusco A, Santoro M, Fagin JA, Nikiforov YE 2003 BRAF mutations in thyroid tumors are restricted to papillary carcinomas and anaplastic or poorly differentiated carcinomas arising from papillary carcinomas. J Clin Endocrinol Metab 88:5399-5404.

6. Fagin JA, Matsuo K, Karmakar A, Chen DL, Tang SH, Koeffler HP 1993 High prevalence of mutations of the p53 gene in poorly differentiated human thyroid carcinomas. J Clin Invest 91:179-184.

7. Liu X, Bishop J, Shan Y, Pai S, Liu D, Murugan AK, Sun H, El-Naggar AK, Xing M 2013 Highly prevalent TERT promoter mutations in aggressive thyroid cancers. Endocr Relat Cancer 20:603-610.

8. Landa I, Ganly I, Chan TA, Mitsutake N, Matsuse M, Ibrahimpasic T, Ghossein RA, Fagin JA 2013 Frequent somatic TERT promoter mutations in thyroid cancer: higher prevalence in advanced forms of the disease. J Clin Endocrinol Metab 98:E1562-E1566.

9. Wang JR, Zafereo ME, Dadu R, Ferrarotto R, Busaidy NL, Lu C, Ahmed S, Gule-Monroe MK, Williams MD, Sturgis EM, Goepfert RP, Gross ND, Lai SY, Gunn GB, Phan J, Rosenthal DI, Fuller CD, Morrison WH, Iyer P, Cabanillas ME 2019 Complete surgical resection following neoadjuvant dabrafenib plus trametinib in BRAF(V600E)-mutated anaplastic thyroid carcinoma. Thyroid 29:1036-1043.

10. Cabanillas ME, Ferrarotto R, Garden AS, Ahmed S, Busaidy NL, Dadu R, Williams MD, Skinner H, Gunn GB, Grosu H, Iyer P, Hofmann MC, Zafereo M 2018 Neoadjuvant BRAF- and immune-directed therapy for anaplastic thyroid carcinoma. Thyroid 28:945-951.

11. Iorio MV, Croce CM 2009 MicroRNAs in cancer: small molecules with a huge impact. J Clin Oncol 27:5848-5856.

12. Takakura S, Mitsutake N, Nakashima M, Namba H, Saenko VA, Rogounovitch TI, Nakazawa Y, Hayashi T, Ohtsuru A, Yamashita S 2008 Oncogenic role of miR-17-92 cluster in anaplastic thyroid cancer cells. Cancer Sci 99:1147-1154.

13. Hayashita Y, Osada H, Tatematsu Y, Yamada H, Yanagisawa K, Tomida S, Yatabe Y, Kawahara K, Sekido Y, Takahashi T 2005 A polycistronic microRNA cluster, miR17-92, is overexpressed in human lung cancers and enhances cell proliferation. Cancer Res 65:9628-9632.

14. He L, Thomson JM, Hemann MT, Hernando-Monge E, Mu D, Goodson S, Powers S, Cordon-Cardo C, Lowe SW, Hannon GJ, Hammond SM 2005 A microRNA polycistron as a potential human oncogene. Nature 435:828-833.

15. Wan PT, Garnett MJ, Roe SM, Lee S, Niculescu-Duvaz D, Good VM, Jones CM, Marshall CJ, Springer CJ, Barford D, Marais R 2004 Mechanism of activation of the RAF-ERK signaling pathway by oncogenic mutations of B-RAF. Cell 116: $855-867$.

16. Swierniak M, Wojcicka A, Czetwertynska M, Stachlewska E, Maciag M, Wiechno W, Gornicka B, Bogdanska M, 
Koperski L, de la Chapelle A, Jazdzewski K 2013 In-depth characterization of the microRNA transcriptome in normal thyroid and papillary thyroid carcinoma. J Clin Endocrinol Metab 98:E1401-E1409.

17. Fuziwara CS, Kimura ET 2014 High iodine blocks a Notch/ miR-19 loop activated by the BRAF(V600E) oncoprotein and restores the response to TGFbeta in thyroid follicular cells. Thyroid 24:453-462.

18. Mitsutake N, Knauf JA, Mitsutake S, Mesa C, Jr., Zhang L, Fagin JA 2005 Conditional BRAFV600E expression induces DNA synthesis, apoptosis, dedifferentiation, and chromosomal instability in thyroid PCCL3 cells. Cancer Res 65:2465-2473.

19. Ricarte-Filho JC, Ryder M, Chitale DA, Rivera M, Heguy A, Ladanyi M, Janakiraman M, Solit D, Knauf JA, Tuttle RM, Ghossein RA, Fagin JA 2009 Mutational profile of advanced primary and metastatic radioactive iodinerefractory thyroid cancers reveals distinct pathogenetic roles for BRAF, PIK3CA, and AKT1. Cancer Res 69: 4885-4893.

20. Fuziwara CS, Kimura ET 2017 MicroRNAs in thyroid development, function and tumorigenesis. Mol Cell Endocrinol 456:44-50.

21. Ran FA, Hsu PD, Lin CY, Gootenberg JS, Konermann S, Trevino AE, Scott DA, Inoue A, Matoba S, Zhang Y, Zhang F 2013 Double nicking by RNA-guided CRISPR Cas9 for enhanced genome editing specificity. Cell 154: 1380-1389.

22. Ran FA, Hsu PD, Wright J, Agarwala V, Scott DA, Zhang F 2013 Genome engineering using the CRISPR-Cas9 system. Nat Protoc 8:2281-2308.

23. Simon P 2003 Q-Gene: processing quantitative real-time RT-PCR data. Bioinformatics 19:1439-1440.

24. TargetScan. Massachusetts Institute of Technology. Target Scan Human. Available at www.targetscan.org (accessed February 1, 2014).

25. Garcia B, Santisteban P 2002 PI3K is involved in the IGF-I inhibition of TSH-induced sodium/iodide symporter gene expression. Mol Endocrinol 16:342-352.

26. Espinoza CR, Schmitt TL, Loos U 2001 Thyroid transcription factor 1 and Pax 8 synergistically activate the promoter of the human thyroglobulin gene. J Mol Endocrinol 27:59-67.

27. Grasberger H, Ringkananont U, Lefrancois $\mathrm{P}, \mathrm{Abramowicz}$ M, Vassart G, Refetoff S 2005 Thyroid transcription factor 1 rescues PAX8/p300 synergism impaired by a natural PAX8 paired domain mutation with dominant negative activity. Mol Endocrinol 19:1779-1791.

28. Du P, Wang L, Sliz P, Gregory RI 2015 A biogenesis step upstream of microprocessor controls miR-17 approximately 92 expression. Cell 162:885-899.

29. Dews M, Fox JL, Hultine S, Sundaram P, Wang W, Liu YY, Furth E, Enders GH, El-Deiry W, Schelter JM, Cleary MA, Thomas-Tikhonenko A 2010 The myc-miR-17 92 axis blunts TGF $\{$ beta signaling and production of multiple TGF $\{$ beta $\}$-dependent antiangiogenic factors. Cancer Res 70:8233-8246.

30. O'Donnell KA, Wentzel EA, Zeller KI, Dang CV, Mendell JT 2005 c-Myc-regulated microRNAs modulate E2F1 expression. Nature 435:839-843.

31. Frederick JP, Liberati NT, Waddell DS, Shi Y, Wang XF 2004 Transforming growth factor beta-mediated transcriptional repression of c-myc is dependent on direct binding of
Smad3 to a novel repressive Smad binding element. Mol Cell Biol 24:2546-2559.

32. Yuasa R, Eggo MC, Meinkoth J, Dillmann WH, Burrow GN 1992 Iodide induces transforming growth factor beta 1 (TGF-beta 1) mRNA in sheep thyroid cells. Thyroid 2:141145.

33. Frezzetti D, Reale C, Cali G, Nitsch L, Fagman H, Nilsson O, Scarfo M, De Vita G, Di Lauro R 2011 The microRNAprocessing enzyme Dicer is essential for thyroid function. PLoS One 6:e27648.

34. Rodriguez W, Jin L, Janssens V, Pierreux C, Hick AC, Urizar E, Costagliola S 2012 Deletion of the RNaseIII enzyme dicer in thyroid follicular cells causes hypothyroidism with signs of neoplastic alterations. PLoS One 7: e29929.

35. Volinia S, Calin GA, Liu CG, Ambs S, Cimmino A, Petrocca F, Visone R, Iorio M, Roldo C, Ferracin M, Prueitt RL, Yanaihara N, Lanza G, Scarpa A, Vecchione A, Negrini M, Harris CC, Croce CM 2006 A microRNA expression signature of human solid tumors defines cancer gene targets. Proc Natl Acad Sci U S A 103:2257-2261.

36. Galrao AL, Camargo RY, Friguglietti CU, Moraes L, Cerutti JM, Serrano-Nascimento C, Suzuki MF, MedeirosNeto G, Rubio IG 2014 Hypermethylation of a new distal sodium/iodide symporter (NIS) enhancer (NDE) is associated with reduced NIS expression in thyroid tumors. J Clin Endocrinol Metab 99:E944-E952.

37. Knauf JA, Ma X, Smith EP, Zhang L, Mitsutake N, Liao XH, Refetoff S, Nikiforov YE, Fagin JA 2005 Targeted expression of BRAFV600E in thyroid cells of transgenic mice results in papillary thyroid cancers that undergo dedifferentiation. Cancer Res 65:4238-4245.

38. Xing M, Alzahrani AS, Carson KA, Viola D, Elisei R, Bendlova B, Yip L, Mian C, Vianello F, Tuttle RM, Robenshtok E, Fagin JA, Puxeddu E, Fugazzola L, Czarniecka A, Jarzab B, O'Neill CJ, Sywak MS, Lam AK, RiescoEizaguirre G, Santisteban P, Nakayama H, Tufano RP, Pai SI, Zeiger MA, Westra WH, Clark DP, Clifton-Bligh R, Sidransky D, Ladenson PW, Sykorova V 2013 Association between BRAF V600E mutation and mortality in patients with papillary thyroid cancer. JAMA 309:1493-1501.

39. Xing M, Westra WH, Tufano RP, Cohen Y, Rosenbaum E, Rhoden KJ, Carson KA, Vasko V, Larin A, Tallini G, Tolaney S, Holt EH, Hui P, Umbricht $\mathrm{CB}$, Basaria S, Ewertz M, Tufaro AP, Califano JA, Ringel MD, Zeiger MA, Sidransky D, Ladenson PW 2005 BRAF mutation predicts a poorer clinical prognosis for papillary thyroid cancer. J Clin Endocrinol Metab 90:6373-6379.

40. Riesco-Eizaguirre G, Gutierrez-Martinez P, GarciaCabezas MA, Nistal M, Santisteban P 2006 The oncogene BRAF V600E is associated with a high risk of recurrence and less differentiated papillary thyroid carcinoma due to the impairment of $\mathrm{Na}+/ \mathrm{I}-$ targeting to the membrane. Endocr Relat Cancer 13:257-269.

41. Lakshmanan A, Wojcicka A, Kotlarek M, Zhang X, Jazdzewski K, Jhiang SM 2015 microRNA-339-5p modulates $\mathrm{Na}+/ \mathrm{I}-$ symporter-mediated radioiodide uptake. Endocr Relat Cancer 22:11-21.

42. Riesco-Eizaguirre G, Wert-Lamas L, Perales-Paton J, SastrePerona A, Fernandez LP, Santisteban P 2015 The miR-146b3 p/PAX8/NIS regulatory circuit modulates the differentiation phenotype and function of thyroid cells during carcinogenesis. Cancer Res 75:4119-4130. 
43. Li Y, Choi PS, Casey SC, Dill DL, Felsher DW 2014 MYC through miR-17-92 suppresses specific target genes to maintain survival, autonomous proliferation, and a neoplastic state. Cancer Cell 26:262-272.

44. Barrangou R, Doudna JA 2016 Applications of CRISPR technologies in research and beyond. Nat Biotechnol 34: 933-941.

45. Yang S, Chang R, Yang H, Zhao T, Hong Y, Kong HE, Sun X, Qin Z, Jin P, Li S, Li XJ 2017 CRISPR/Cas9-mediated gene editing ameliorates neurotoxicity in mouse model of Huntington's disease. J Clin Invest 127:2719-2724.

46. Ma H, Marti-Gutierrez N, Park SW, Wu J, Lee Y, Suzuki K, Koski A, Ji D, Hayama T, Ahmed R, Darby H, Van Dyken C, Li Y, Kang E, Park AR, Kim D, Kim ST, Gong J, Gu Y, Xu X, Battaglia D, Krieg SA, Lee DM, Wu DH,
Wolf DP, Heitner SB, Belmonte JCI, Amato P, Kim JS, Kaul S, Mitalipov S 2017 Correction of a pathogenic gene mutation in human embryos. Nature 548:413-419.

Address correspondence to: Edna Teruko Kimura, MD, PhD

Department of Cell and Developmental Biology Institute of Biomedical Sciences University of São Paulo Avenida Professor Lineu Prestes, 1524, Room 414 Butantã, São Paulo CEP 05508-000

Brazil

E-mail: etkimura@usp.br 